\title{
Manajemen Peningkatan Kompetensi Tenaga Pendidik pada Madrasah Tsanawiyah Negeri Olak Kemang
}

\begin{abstract}
Nuraini ${ }^{1}$
Abstrak: Tujuan penelitian ini ingin mengetahui manajemen peningkatan kompetensi tenaga pendidik, faktor pendukung dan penghambat peningkatan kompetensi tenaga pendidik serta upaya manajemen peningkatan kompetensi tenaga pendidik di MTsN Olak Kemang Kota Jambi. Penelitian ini menggunakan pendekatan kualitatif, pengumpulan data dilakukan dengan tehnik observasi, wawancara dan dokumentasi. Penentuan subjek penelitian menggunakan teknik purposive sampling, teknik analisis data dilakukan dengan reduksi data, penyajian data dan verifikasi / penarikan kesimpulan, sedangkan pengecekan keabsahan data dilakukan dengan trianggulasi, pembicaraan dengan kolega dan mengadakan member check. Hasil penelitian ini menunjukkan bahwa manajemen peningkatan kompetensi tenaga pendidik pada Madrasah Tsanawiyah Negeri Olak Kemang Kota Jambi berjalan masih belum maksimal antara lain : guru belum sepenuhnya ingin mengikuti pelatihan metode penulisan ilmiah, belum mengikuti forum ilmiah antar guru, belum terbiasa membaca hingga dua jam perhari dan juga jarang mengunjungi sumber belajar serta lembaga ilmiah, beberapa faktor pendukung peningkatan kompetensi tenaga pendidik mada Madrasah Tsanawiyah Negeri Olak Kemang Kota Jambi antara lain : semua guru sudah berkualifikasi S1 dan sudah memperoleh sertifikat sertifikasi, upaya peningkatan kompetensi tenaga pendidik dapat dilakukan melalui beberapa cara antara lain: pendidikan lanjut S1 ke S2, mengikuti pelatihan profesi, mengikuti program supervise, memberdayakan MGMP, menuli jurnal ilmiah, melakukan penelitian, mengikuti program magang dan menggalang kerja sama dengan rekan seprofesi.
\end{abstract}

Kata kunci : Manajemen, Kompetensi, Tenaga Pendidik

Abstract: This Study aim to ind out the management of increasing the competence of teaching staff, supporting factors and inhibitors of improving the competence of teaching staff and management efforts to increase the competency of teaching staff at MTsN Olak Kemang, Jambi City. This study uses a qualitative approach, data collection is done by observation, interview and documentation techniques. Determination of research subjects using purposive sampling technique, data analysis techniques carried out by data reduction, data presentation and verification / conclusion drawing, while checking the validity of the data is done by triangulation, talking with colleagues and holding member checks. The results of this study indicate that the management of improving the competency of teaching staff in the Jambi City Olak Kemang Madrasah Tsanawiyah still not optimal, among others: teachers do not fully want to take part in scientific writing training methods, have not attended scientific forums between teachers, are not used to reading up to two hours per day and also rarely visit learning resources and scientific institutions. Some of the supporting factors for increasing the competence of teaching staff in the Olak Kemang State Islamic Primary School in Jambi include: all teachers have S1 qualifications and have obtained certification certificates, efforts to improve the competence of educators can be done in several ways including: S1 advanced education to S2, training profession, taking part in the supervision program, empowering the MGMP, writing scientific journals, conducting research, taking part in an internship program and collaborating with colleagues.

Keyword : Management, Competence, Educators

\section{PENDAHULUAN}

Dalam upaya peningkatan sumber daya manusia (SDM), peranan pendidikan cukup menonjol, oleh karena itu sangat penting pembangunan nasional memfokuskan peningkatan mutu pendidikan. Pendidikan yang bermutu akan diperoleh pada sekolah yang bermutu dan sekolah yang bermutu akan menghasilkan SDM yang bermutu pula. Salah satu strategi yang menentukan mutu pengembangan SDM di sekolah untuk kompetisi antar negara di era globalisasi ini mutu produk dan pelayanan yang dihasilkan berbagai lembaga pendidikan ditentukan oleh kompetensi manajerial, kepemimpinan, visi dan integritas, kepribadian para manajer, guru-guru dan pegawai dalam mengelola pendidikan (Syarifuddin, 2002). Demikian pula kontribusi para insinyur dan ekonomi dari dunia industry dituntut partisipasinya bagi dunia pendidikan, para manajer di dunia bisnis, industri, pabrikasi dan perbankan, baik dalam pemikiran maupun tindakan mereka dalam membuat keputusan tentang mutu ketenagaan perlu ada relevansinya dengan dunia pendidikan.

\footnotetext{
${ }^{1}$ Guru Pendidikan Agama Islam, SMP Negeri 1 Kota Jambi
} 
Karena itu, tuntutan perbaikan mutu pendidikan perlu direspons dan dijadikan isu utama penyusunan strategi pendidikan nasional untuk memenuhi permintaan (deman) SDM unggul sebagai subjek pembangunan hari ini dan mendatang.

Beberapa upaya peningkatan mutu pendidikan sekolah di Indonesia telah dilakukan dengan berbagai cara, diantaranya melalui pengembangan dan perbaikan kurikulum, sistem evaluasi, sarana pendidikan, materi ajar serta mutu guru dan tenaga pendidik lainnya. Namun, upaya tersebut belum memperlihatkan dampak yang signifikan terhadap peningkatan mutu pendidikan di negeri ini. Hal itu di indikasikan dengan nilai hasil evaluasi belajar untuk berbagai bidang studi pada jenjang menengah yang cenderung tidak menunjukkan peningkatan yang berarti, bahkan dapat dikategorikan konstan dari tahun ke tahun.

Dua faktor penting yang dapat menjelaskan mengapa upaya perbaikan mutu pendidikan selama ini kurang atau tidak berhasil yaitu : pertama, strategi pembangunan pendidikan lebih bersifat input oriented, dan kedua pengelolaan lebih bersifat macro oriented, strategi input output diperkenalkan oleh teori education production function yang berstandar pada asumsi bahwa apabila semua input pendidikan telah dipenuhi, seperti penyediaan buku paket dan alat belajar lainnya, penyediaan sarana pendidikan, pelatihan guru serta tenaga pendidik, maka secara otomatis sekolah akan dapat menghasilkan keluasan yang bermutu. Faktor kekurangberhasilannya adalah input dari siswa sangatlah beragam. Strategi pengelolaan yang macro oriented berarti bahwa pengelolaan pendidikan diatur terlalu dominan oleh jajaran birokrasi di tingkat pusat. Akibatnya, banyak yang tidak berjalan sebagaimana mestinya di tingkat mikro.

Pembangunan pendidikan bukan hanya terfokus pada penyediaan faktor input pendidikan semata-mata tetapi harus juga memperhatikan faktor proses input pendidikan merupakan hal yang mutlak tetapi tidak menjadi jaminan dapat secara otomatis meningkatkan mutu pendidikan mengingat sekolah sebagai unit pelaksana pendidikan formal terdepan dengan berbagai keseragaman potensi anak didik, tentunya harus mampu menyediakan layanan pendidikan yang beragam dan kondisi lingkungan yang berbeda dengan lainnya. Oleh karena itu sekolah harus dinamis dan kreatif dalam melaksanakan perannya untuk mengupayakan mutu pendidikan.

Sebagai pendidik professional, guru bukan saja dituntut melaksanakan tugasnya secara profesional, tetapi juga harus memiliki pengetahuan dan kemampuan professional. Tenaga kependidikan yang diselenggarakan oleh PPS IKIP Bandung tahun 1990, dirumuskan 10 ciri suatu profesi yaitu (1) memiliki fungsi dan signifikansi sosial, (2) memiliki keahlian / keterampilan tertentu, (3) keahlian / keterampilan diperoleh dengan menggunakan teori dan metode ilmiah, (4) didasarkan atas disiplin ilmu yang kuat, (5) diperoleh dengan pendidikan dalam masa tertentu yang cukup lama, (6) aplikasi dan sosialisasi nilai-nilai professional, (7) memiliki kode etik, (8) kebebasan untuk memberikan judgement dalam memecahkan maslah dalam lingkungan kerjanya, (9) memiliki tanggung jawab professional dan otonomi dan, (10) ada pengakuan dari masyarakat dan imbalan atas layanan profesinya (Abudin, 2010)

Direktur Jenderal Pendidikan Dasar mengemukakan bahwa pada tahun 2000, 60 persen guru Sekolah Dasar (SD), 40 persen guru Sekolah Lanjutan Tingkat Pertama (SLTP), 43 persen guru Sekolah Menengah Umum (SMU) serta 34 persen guru Sekolah Menengah Kejuruan (SMK), belum memenuhi kualifikasi sebagai guru yang seharusnya disyaratkan untuk bertugas di masing-masing jenjang itu. Di samping itu banyak guru yang mengajar tidak sesuai dengan bidang studi yang ditekuni dalam pendidikan prajabatan mereka, semua persoalan ini tidak semata-mata menyangkut keputusan profesional dalam sistem pendidikan nasional, tetapi juga keputusan politik, sosial, ekonomi dan bidang-bidang lainnya dalam kehidupan berbangsa dan bernegara.

Tujuan penelitian ini ingin mengetahui manajemen peningkatan kompetensi tenaga pendidik dan faktor pendukung dan penghambat peningkatan kompetensi tenaga pendidik serta upaya manajemen peningkatan kompetensi tenaga pendidik di MTsN Olak Kemang Kota Jambi. Sesuai dengan permasalahan penelitian, ruang lingkup penelitian ini terfokus mengenai manajemen peningkatan tenaga pendidik di Madrasah Tsanawiyah Negeri Olak Kemang Kota Jambi.

Dalam Undang-Undang Republik Indonesia No. 20 Tahun 2003 tentang Sistem Pendidikan Nasional dijelaskan bahwa pendidik adalah tenaga kependidikan yang berkualifikasi sebagai guru, dosen, konselor, pamong belajar, widyaiswara, tutor, instruktur, fasilitator, dan sebutan lain yang sesuai dengan kekhususannya, serta berpartisipasi dalam menyelenggarakan pendidikan. 
Dalam konteks pendidikan, pengertian mutu mengacu pada masukan, proses, keluaran dan dampaknya. Mutu masukan dapat dilihat dari berbagai sisi. Pertama, kondisi baik atau tidaknya masukan sumber daya manusia seperti kepala sekolah, guru, staf tata usaha, dan siswa. Kedua, memenuhi atau tidaknya kriteria masukan material berupa alat peraga, buku-buku kurikulum, prasarana dan sarana sekolah. Ketiga, memenuhi atau tidaknya kriteria masukan yang berupa alat lunak, seperti peraturan struktur organisasi, deskripsi kerja, dan struktur organisasi. Keempat, mutu masukan yang bersifat harapan dan kebutuhan seperti visi, motivasi, ketekunan dan cita-cita (Denim, 2003).

Pendidik atau guru dalam konteks Islam sering disebut dengan murabbi, mu'allim,dan mu'addib yang pada dasarnya mempunyai makna yang berbeda sesuai dengan konteks kalimat walaupun dalam situasi tertentu mempunyai kesamaan makna, kata murabbi berasal dari kata rabba, yurabbi, kata mu'allim berasal dari kata 'allama, yu'allimu, sedangkan kata mu'addib berasal dari kata addaba, yuaddabu sebagaimana sebuah ungkapan: Allah mendidikku, maka ia memberikan kepadaku sebaik-baiknya pendidikan. Menurut Moh. Fadhil A Jamali dalam Nafis, pendidik adalah orang yang mengarahkan manusia kepada kehidupan yang baik sehingga terangkat derajat kemanusiaanya sesuai dengan kemampuan dasar manusia (Nafis, 2011)

Menurut Mulyasa (2011) Kompetensi memiliki banyak sekali pengertian. Beberapa pakar seperti Broke and Stone mengemukakan bahwa kompetensi guru sebagai desprective of qualitative nature of teacher behavior appears to be entirely meaningfull (kompetensi guru merupakan gambaran kualitatif tentang hakikat perilaku guru yang penuh arti).

Lebih lanjut Spencer dan Spencer (dalam Hamzah B. Uno, 2007) Mengemukakan bahwa "Kompetensi merupakan karakteristik yang menonjol bagi seseorang dan menjadi cara-cara berperilaku dan berfikir dalam segala situasi, dan berlangsung dalam periode waktu yang lama". Dari pendapat tersebut dapat difahami bahwa kompetensi menunjuk pada kinerja seseorang dalam suatu pekerjaan yang bisa dilihat dari pikiran, sikap, dan perilaku. Sedangkan Suyanto dan Jihad (2013) mengemukakan bahwa : kompetensi pada dasarnya merupakan deskripsi tentang apa yang dapat dilakukan seseorang dalam bekerja, serta apa wujud darinpekerjaantersebut yang dapat dilihat. Untuk dapat melakukan suatu pekerjaan, seseorang harus memiliki kemampuan dalam bentuk pengetahuan, sikap, keterampilan yang relevan dengan bidang pekerjaannya. Mengacu pada pengertian tersebut, kompetensi guru dapat dimaknai sebagai gambaran tentang apa yang bharus dilakukan seorang guru dalam melaksanakan pekerjaannya, baik berupa kegiatan, perilaku maupun hasil yang dapat ditunjukan dalam proses belajar mengajar.

Kompetensi guru adalah seperangkat penguasaan kemampuan yang harus ada dalam diri guru agar dapat mewujudkan kinerjanya secara tepat dan efektif (Kunandar, 2007). Di dalam pasal 10 ayat (1) UU guru dan dosen No. 14 tahun 2005 dinyatakan bahwa kompetensi guru meliputi kompetensi paedagogik, kompetensi kepribadian, kompetensi sosial, dan kompetensi profesonal yang diperoleh melalui pendidikan profesi. Sehingga dapat disimpulkan bahwa Kompetensi guru merupakan perpaduan antara kemampuan personal, keilmuan, teknologi, sosial, dan spiritual yang secara kaffah membentuk kompetensi standar profesi guru, yang mencangkup penguasaan materi, pemahaman terhadap peserta didik, pembelajaran yang mendidik, pengembangan pribadi dan profesioanalisme.

\section{METODE PENELITIAN}

Metode Penelitian ini merupakan sebuah studi yang akan mengungkapkan informasi mengenai pemberdayaan tenaga pendidik pada Madrasah Tsanawiyah Negeri Olak Kemang Kota Jambi. Pendekatan yang dipakai peneliti adalah pendekatan kualitatif. Pendekatan kualitatif yang dimaksud adalah peneliti mencari literature / teori yang berakitan dengan penelitian, kemudian teori tersebut dibandingkan dengan kondisi yang berhubungan dengan penelitian ini. Pada penelitian kualitatif ada tiga kemungkinan yang akan terjadi pada maslah yang dibawa oleh peneliti dalam penelitian, pertama maslah yang dibawakan peneliti bersifat tetapi, sehingga dari awal hingga akhir peneliti hasilnya tetapi sama. Hal ini ditunjukkan dengan judul proposal dengan judul paparan penelitian masih sama. Kedua malah yang ditemukan peneliti makin berkembang, sehingga memperdalam dan memperluas masalah yang dibawa dari semula, namun demikian, perubahan tidak terlalu banyak terjadi sehingga hanya terjadi perbaikan judul pada laporan penelitian. Ketiga, masalah yang dibawa peneliti ke lapangan mengalami perubahan total, sehingga harus ganti masalah. 
Pendekatan kualitatif dipilih karena data yang dihasilkan berupa data deskriptif yang diperoleh dari data-data berupa tulisan, kata-kata dan dokumen yang berasal dari sumber atau informan yang diteliti dan dapat dipercaya. Alasan lain mengapa metode ini digunakan secara luas adalah bahwa data yang dikumpulkan dianggap sangat bermanfaat dalam membantu untuk menyelesaikan atau memecahkan masalah-masalah yang timbul dalam kehidupan sehari-hari.

\section{HASIL DAN PEMBAHASAN}

Implementasi manajemen peningkatan kompetensi tenaga pendidik di Madrasah Tsanawiyah Negeri Olak Kemang Kota Jambi dari aspek kualifikasi dapat diketahui bahwa semua tenaga pendidik yang berjumlah 30 orang telah berkualifiaksi S1 bahkan ada yang sedang mengikuti (S2). Hal ini menunjukkan semua guru telah memenuhi syarat kualifikasi standar bagi tenaga pendidik pada jenjang Madrasah Tsnawiyah. Begitu pula dengan bidang studi yang menjadi beban mengajar para guru tersebut, meskipun masih terdapat 4 orang tenaga pendidik yang mengajar tidak sejalan dengan ilmu kesarjanaannya, namun telah memperoleh penyesuaian melalui diklat sertifikasi dan telah memiliki sertifikat sesuai dengan mata pelajaran yang diajarkan, sebanyak 26 orang telah mengajar sesuai dengan bidang keahlian yang ditempuh pada saat mengambil gelar kesarjanaan.

Berkaitan dengan kompetensi guru, Kementerian Pendidikan menyatakan bahwa krakteristik guru yang baik meliputi hal-hal sebagai berikut : (1) memahami dan menghormati murid sebagai manusia, ingat tentang eksistensi manusia yang memiliki empat eksistensi yaitu : makhluk religious, individu, sosial dan makhluk susila, (2) harus menghormati bahan pelajaran yang diberikannya, dengan demikian ia harus berusaha menguasia bidang studi yang diajarkannya serta kegunaa dan manfaatnya bagi kehidupan anak, (3) mampu menyesuaikan strategi mengajar dengan bahan pengajaran, (4) mampu menyesuaikan bahan pengajaran dengan mempertimbangkan kesanggupan murid, (5) mampu mengembangkan CBSA (Pakem, CTL) dan keterampilan proses dalam pembelajaran untuk mengomptimalkan hasil belajar, (6) pemahaman / pengertian kepada anak dengan prinsip peragaan, (7) selalu berusaha menghubungkan bahan pelajaran dengan kebutuhan muridnya, sehingga minat belaja rnaka akan tumbuh, (8) mampu merumuskan tujuan pembelajaran tertentu untuk setiap pelajaran yang diberikannya, (9) mampu memperkaya atau mengembangkan bahan ajar yang diberikan kepada siswa, tidak hanya bersifat buku teks (teks book) saja (10) tidak hanya menyampaikan pengetahuan kepada murid, tetapi selalu berusaha mengembangkan dan membentuk pribadi.

a. Mengikuti pendidikan profesi yang diselenggarakan oleh perguruan tinggi terakreditasi yang ditunjuk oleh pemerintah

Profesi guru diakui dalam bentuk pemberian penghargaan berupa sertifikat profesi. Dampak berikutnya adalah penerimaan tunjangan profesi yang diterima oleh guru yang bersertifikat tersebut. Dari 30 orang guru, terdapat 26 orang guru yang telah menjalani pelatihan profesi dan menerima sertifikat melalui bentuk pengakuan ini, guru Madrasah diharapkan dapat membtuktikan profesionalitas mereka dengan cara memperbaiki kinerja dalam mengajar yang berkualitas.

Situasi tersebut sejalan dengan peraturan pemerinth No. 74 Tahun 2008 tentang guru. Dalam pasla 1 ayat 1 disebutkan bahwa, guru adalah pendidik professional dengan tugas utama mendidik, mengajar, mendidik pada pendidikan anka usia dini jalur pendidikan formal, pendidikan dasar dan pendidikan menengah. Dari pengertian-pengertian tersebut dapat diambil kesimpulan bahwa yang dimaksud tenaga kependidikan dapat dibagi menjadi dua yaitu tenag akependidikan fungsional dan tenaga pendidik teknisi. Tenaga fungsional merupakna tenaga kependidikan yang menempait jabatanjabatan fungsional yakni jabatan-jabatan keahlian akademis kependidikan seperti guru, onselor, supervisor, ahli kurikulum dan sebagainya. Sedangkan tenaga teknis kependidikan merupakan tenaga kependidikan yang dalam pelaksanaan pekerjaannya lebih dituntut kecapakan teknis operasional dan administrative seperti pustakawan, laboran sekolah dan sebagainya.

b. Mengikuti pelatihan dan lokakarya yang sesuai dengan bidang keahliannya

Pelatihan yang diikuti oleh guru pada umumnya menunggu undangan dari penyelenggaraan yang biasanay berasla dari Kementerian Agama dan pelatihan yang diikuti sesuai dengan mata pelajaran yang biasa mereka asuh. Dengan menunggu undangan penyelenggaraan pelatihan dari pemerintah, maka tidak semua guru bisa mengikuti karena terbatas oleh kuota, sehingga pelatihan biasnaya hanya sekali 
dalam setahun. Pihak Madrasah mendahulukan guru senior, sehingga guru lain jarang mengikuti pelatihan atau lokakarya.

c. Mengikuti pelatihan penelitian tindakan kelas dan melaksanakannya di sekolahnya untuk perbaikan pembelajaran

Selain bertugas mengajar, guru diharapkan bisa melakukan penelitian terkait dengan bidang studi atau pelajarna yang diasuh. Penelitian ini berguna untuk mengevaluasi pembelajaran. selama ini dijalnakn melalui kerjasama dengan guru atau kepala skeolah, guru dapat melakukan penelitian tindakan kelas secara umum penelitian tindakan kelas membawa manfaat langsung mengenai metode yang dipilih guru dalam mengajar. Guru yang sering melakukan penelitian akan mendapaktna alternative dalam memilih metode yang lebih efektif sehingga hasil maksimal dapat diperoleh.

d. Mengikuti pelatihan penulisan karya ilmiah dalam bidang profesinya

Selain penelitian tindakan kelas, guru juga dapat melkaukan penelitian ilmiah lainnya namun hal ini jarang terjadi pada MTsN Olak Kemang sejauh yang diamati melalui dokumen ataupun observasi serta wawancara tidak ada yang menyatakan bahwa guru pernah mengikuti penulisan karya ilmiah.

e. Mengikuti kegiatan forum ilmiah sesuai bidangnya seperti seminar, semiloka, diskusi panel konfrensi, konvensi dan temu ilmiah

Sama seperti halnya kegiatan pelatihan penulisan karya ilmiah, kegiatan seminar semiloka, diskusi ataupun bentuk pertemuan ilmiah lainnya masih jarang diikuti oleh guru madrasha, kegiatan seminar jarang disleenggarakan, sehingga jarang pula mengikutsertakan guru kalaupun ikut, guru yang mengikuti terbatas.

f. Belajar secara berkelompok melalui forum KKG, MGMP dan lain-lainnya

Musyawarah antar guru sangat diperlukan dalam upaya saling berbagi informasi tentang pembelajaran, metode evaluasi atau apapun yang dapat meningkatkna kinerja dan kualitas pembelajaran. pada sekolah umumnya musyawarah ini terbentuk sesuai dengan bideang studi atau mata pelajarna ygn diajarkan oleh anggota, lempko musyawarah ini dikenal dengan sebutan musyawarah guru mata pelajaran. (MGMP) untuk kalangan Madrasah dikenal dengan KKM atau kelompok kerja Madrasah, yang digerakkan oleh kepala Madrasah dalam rangka meingkakan kinerja dan profesionalitas guru.

Implementasi manajemen peningkatan tenaga pendidik di MTsN Olak Kemang Kota Jambi dari aspek pedagogis diantaranya sebagai berikut:

a. Belajar secara mandiri dan dilakukan secara terus menerus

Guru yang punya semangat profesional tidak akan menyia-nyiakan waktunya terbuang percuma. Karena itu, selain mendapatkan masukan atau menimba pengalaman dari pihak lain, guru juga akan belajar autodidak atas hal-hal yang baru yang belum bisa dikuasainya. Demikianlah yang menjadi harapan kepala madrasah ketika ditanyakan tentang semangat profesionalitas guru di Madrasah.

b. Memperlajari modul-modul pendidikan guru berbasis kompetensi

Belajar otodidak yang dilakukan guru dapat memanfaatkan beberapa sumber yang valid dan relevan, tidak saja melalui buku-buku teapi dapat pula melalui modul-modul yang telah disusun oleh para pakar pendidikan. Modul tersebu disusun untuk meningkatkan kompetensi dan profesionalitas guru pada sekolah modul biasnaya disertai latihan yagn tercantum pada akhir suatu kajian. Guru dapat mencoba kemampuannya dengan menjawab latihan untuk mengukur sejauh mana penguasaannya terhadap materi kajian tersebut.

c. Belajar dari kesalahan dan melakukan perbaikan atas kekurangannya

Guru bukanlah makhluk, meski dihadapan siswanya guru terlihat seperti tahu segalanya, namun tidak persis seperti demikian kenyataan sesungguhnya terkadang guru masih melakukan kesalahan misalnya dalam pemilihan strategi dan metode mengajar ataupun dalam penggunaan alat dan media belajar. Hal ini menuntut guru untuk dapat berlapang dada dan berupaya memperbaiki diri. Penggunaan teknologi multimedia misalnya, tidak semua guru dapat memanfaatkannya dengan baik karena itu guru perlu mengasah keterampilannya dalam bidang ini.

d. Berkunjung ke pusat kegiatan ilmiah, misalnya LIPI, pusat-pusat penelitian di Perguruan Tinggi, Laboratorium, Perpustakaan dan lain-lain 
Sumber belajar seperti laboratorium yang besar, pusat penelitian, ataupun perpustakaan besar dan lengkap, sulit ditemukan di Jambi. Karena itu MTsN Olak Kemang membuat agenda studi tour ke luar daerah untuk dapat mengunjungi sumber belajar yang lebih bervariasi dan lengkap. Menurut dokumentasi yang ditemukan, MTsN Olak Kemang pernah melakukan perjalanan karya wisata, tempat yang dituju adalah gedung LIPI, Museum IPTEK di Taman Mini, dan Kebun Raya Bogor. Agenda ini tidak rutin dilakukan setiap tahun.

e. Mengunjungi sekolah-sekolah yang unggul

Selain mengunjungi sumber belajar seperti laboratorium, tempat bersejarah atau monumen pada saat studi tour para siswa dan guru juga mengunjungi sekolah favorit dan unggul. Berbagai hal dapat dipelajari pada saat kunjungan tersebut.

f. Membaca buku, jurnal, majalah, hasil penelitian sewa profesinya

Bacaan guru terbatas pada bidang mata pelajaran yang ditekuni dan diajarkan sesuai dengan keahliannya. Kalaupun ada tambahannya, namun bukanlah jurnal atau majalah ilmiah hasil penelitian keadaan para guru mengacu pada ketersediaan buku di perpustakaan sekolah. Mengingat terbatasnya jumlah koleksi buku, apalagi buku jurnal ilmiah, maka secara langsung ataupun tidak turut berdampak pada minimnya bacaan guru. Sedangkan peran dan fungsi guru dalam pembelajaran modern mencakup, pemandu bakat dan potensi siswa untuk menjalankan tugas pokok dan fungsinya tersebut dibutuhkan bekal pengetahuan dan keahlian yang ditopang sikap kerja yang penuh dedikasi terhadap profesi. Pelaksanaan manajemen tenaga pendidik di Indonesia sedikitnya mencakup tujuh kegiatan utama yaitu perencanaan tenaga pendidik, pengadaan tenaga pendidik, pembinaan dan pengembangan tenaga pendidik, promosi dan mutasi, pemberhentian tenaga pendidik, kompensasi dan penilaian tenaga pendidik. Semua itu perlu dilakukan dengan baik dan benar agar diharapkan tercapainya ketersediaannya tenaga pendidik yang diperlukan dengan kualifikasi dan kemampuan yang sesuai serta dapat melaksanakan pekerjaan dengan baik.

\section{SIMPULAN}

Perwujudan dari kualitas guru yang bagus karena produktivitas kerja guru yang tinggi, hal ini cukup penting dalam rangka mencapai tujuan sekolah. Dengan prestasi kerja yang tinggi berarti para guru benarbenar dapat berfungsi sebagai pendidik yang tepat guna sesuai dengan sasaran-sasaran organisasi yang hendak dicapai bersama.

Berdasarkan temuan-temuan penelitian ini ada beberapa rekomendasi yang ditawarkan : 1) Perlu ada jaringan internet yang dapat membuka akses informasi secara luas, 2) Perlu adanya kegiatan ilmiah, symposium, lokakarya, dan seminar yang melibatkan lebih banyak guru dan frekuensi penyelenggaraannya yang perlu ditingkatkan lagi, 3) Perlu ada pelatihan guru untuk meningkatkan kemampuan guru dalam menulis ilmiah dan meneliti, hingga kelak akan memunculkan karya guru yang bermanfaat.

\section{DAFTAR PUSTAKA}

Aang, Sulaiman,.2012.Membangun Sumberdaya Manusia Berkualitas, Sidoarjo: Brilian

Abudin, Nata. 2010.Manajemen Pendidikan. Jakarta : Kencana

Athoillah, Anton. 2010. Dasar-dasar Manajemen. Bandung : Pustaka Setia

Denim, Sudarwan dan Khairil. 2011. Profesi Kependidikan. Bandung : Alfabeta

Denim, Sudarwan . 2003. Agenda Pembaharuan Sistem Pendididan. Yogjakarta: Pustaka Pelajar

Departemen Pendidikan Nasional 2005. Undang-Undang Nomor 14 Tahun 2005, tentang Guru dan Dosen. Jakarta : Depdiknas

Direktorat Jenderal Pendidikan Dasar dan Menengah. Direktorat Tenaga Kependidikan.

Hamzah, Uno B. 2007. Model Pembelajaran Menciptakan Proses Belajar Mengajar yang Kreatif dan Efektif. Jakarta: Bumi Aksara.

Nafis, Muhammad Muntahibun. 2011. Ilmu Pendidikan Islam, Yogyakarta: Teras

Mulyasa, E. 2011. Standar Kompetensi dan Sertifikasi Guru. Bandung: PT remaja Rosda karya

UU RI No. 14 Th. 2005, Guru dan Dosen, (Jakarta: Sinar Grafika, 2006)

Undang-Undang Republik Indonesia No. 20 Tahun 2003 tentang Sistem Pendidikan Nasional 
Suyanto dan Jihad, A. 2013. Menjadi Guru Profesional (Strategi Meningkatkan Kualifikasi dan Kualitas Guru di Era Global). Jakarta: Esensi Erlangga Group

Syarifuddin, 2002. Manajemen Mutu Terpadu dalam Pendidikan. Jakarta : Grasindo 